\title{
CHINA'S HUMAN RIGHTS DIPLOMACY AND THE UYGHUR CRACKDOWN: THE APPEARANCE OF CONSISTENCY AND THE REALITY OF CONTRADICTION. CHINA'S DOUBLE STANDARDS IN HUMAN RIGHTS
}

\author{
Sadia Rahman and Wei-En Tan \\ National Chung Hsing University
}

\begin{abstract}
What is the impact of China's official human rights stance on international human rights discourses/norms? Will China's ambition to change the international human rights framework succeed, resulting in a new normative order in the world of human rights? The article attempts to address these questions. First, it identifies the state's practice pursuing different standards when dealing with human rights issues internationally and domestically. Second, it argues that China is no different from other states when it behaves in a double standard way. The paper maintains, however, that China's double-standard human rights approach is critical for the future development of the international human rights regime since the CCP leadership intends to redefine human rights in its own interests. While China's interests align with most states in the third world, its pursuit of normative design is a threat to the current notion of universal human rights.
\end{abstract}

Keywords: discourse, double-standard diplomacy, regime, international human rights, human rights abuse, China, Uyghur

DOI: https//doi.org/10.3176/tr.2022.1.03

Received 25 October 2021, accepted 17 November 2021, printed and available online 10 March 2022 


\section{Introduction}

It is not uncommon for states to pursue two incompatible approaches to human rights in domestic and international affairs. When it comes to human rights violations such as ethnic cleansing, gender issues, and child abuse, states take a different posture in front of the world than when dealing with such concerns internally (McQuigg 2011). Domestic human rights abuse generates international criticism, however, an overall approach undertaken by the criticized state is that it is a matter of state sovereignty. Such a stance rekindles the debate on the interdependent, interrelated and indivisibility of international human rights regime and state sovereignty (Donnelly and Whelan 2020).

Powerful states prefer to interpret international human rights norms according to their own national interest, so do less powerful states, such as Myanmar, Brunei, Kazakhstan, Saudi Arabia, Egypt, Uganda. This article focuses on the People's Republic of China's (PRC) international stance on human rights and its human rights abuse in Xinjiang to emphasize the shift the international community is enduring with the increase of China's stature as a significant global player. Its interpretation or attempt of alteration of international human rights will have an inclusive influence unlike the less powerful states (Fung 2019). The states' double-standard diplomacy is a common occurrence, but China's double-standard practices in the area of international human rights are particularly significant because its remarkable economic growth has greatly bolstered its diplomatic clout, allowing it to rise to prominence in world affairs (Shambaugh 2020). In other words, it can besides be pondered that China's every activity at the international institutions is being noted worldwide and easy to receive criticism unlike the Western states because China has located its footing at the United Nations (UN) human rights bodies.

Ample literature in light of states' behaviour on human rights violations and states implementing universal human rights norms subsist (Donnelly 2003; Burton 2013) including the contestation of state sovereignty and human rights regime (Delbruck 1982). However, little has been written about what happens if China succeeds in changing the human rights system. Because China adheres to the older version of state sovereignty rather than the modern, which is subjected to limitations (Carrai 2019), this boils down to postulating a central question - what would be the impact of China's double-standard diplomacy in the international human rights regime?

In an attempt to decipher China's trajectory of alteration we treat the international human rights regime as a dependent variable. The anticipated conclusion is that China through alteration is preparing the conduit to favour itself and other autocratic states. Consistent with China's bifurcated version of human rights, our analytical analysis takes two approaches. First, China's stance on international human rights diplomacy; second, the human rights abuse of the Uyghurs by the Chinese Communist Party (CCP) exposes China's inconsistency. Given its track record on domestic human rights issues, such as stifling freedom of expression and cracking down on domestic human rights activists, there is justification for changing the international human rights regime to deflect/silence global criticism of and/or action on its own human rights violations (Burnay 2020). 
Thus, the phrase, China is a rising power should be revised as it has already augmented in power. Its rise puts the framework of international relations and the values of many global institutions in jeopardy (Forsythe 2000). With Xi Jinping's ascension to power the watershed moment emerged for domestic and global governance, one of the prime targets being international human rights institutions (Piccone 2018). Like other powers (established powers like Russia and emerging powers and a swing state like India) that have challenged global institutions' universal ideals, any rising or risen power would also resort to doing when it is on the path of expansionism. China is following suit (Gotz and Merien 2018, Kliman 2012). This veracity of China challenging international institutions' norms is complemented from the third world states' perspective because China enjoys an appeal to thirdworld states (or developing nations), while the crucial P2 nexus (China and Russia) reigns supreme and exerts influence over human rights procedures. Whether the P2 nexus does pose an unprecedented challenge in modifying the international human rights regime or whether China can independently make a difference will also be underscored in the article.

\section{The puzzle}

Although human rights have a long history, the modern concept arose from the trauma of World War II ${ }^{1}$. The international bill is based on three core instruments: the Universal Declaration of Human Rights (UDHR) 1948 and its two binding covenants, the International Covenant on Civil and Political Rights (ICCPR), and the International Covenant on Economic, Social, and Cultural Rights (ICESCR) $1966^{2}$. States like China, which postulate the notion of cultural relativism to gain international support, have utilized the modern concept of transpiration from western philosophy and politics as a subject of disagreement (Burke 2013). Experts such as Falk (1981), Donnelly (1998), and Hagan and Levi (2007) and Rachel George (2020) have described remorseful affairs regarding the enforcement of international conventions that protect human rights in all spheres of social and political life because of state sovereignty. Although state sovereignty is a complicated concept, it is the most important legal and political component of the international order. As members

1 Emerging from the backdrop of World War II rendered the leaders to decide and frame the UN charter enriching guarantees for human beings. In 1947 the UN Commission drafted its preliminary draft of the international bill of human rights. To conclude formally on the draft a formal drafting advisory group took over comprising of the members of the Commission from eight states, Drafting of the Universal Declaration of Human Rights, available online at $<\mathrm{https}$ ://research.un.org/en/undhr/ draftingcommittee>, accessed on 1 September, 2020.

2 The binding human rights instruments were divided into two covenants ICCPR and ICESCR. It was an appropriate stance taken by the leaders to combine the aspects of civil, cultural, political rights but that has been a critical aspect of contestation between states. In our article, we underscore how states despite ratifying the covenants breach it under the semblance of cultural relativism. The United Nations Human Rights Treaty System: An Introduction to the Core Human Rights Treaties and The Treaty Bodies, Office of the United Nations High Commissioner for Human Rights, available online at $<$ https://www.ohchr.org/documents/publications/factsheet30en.pdf $>$, accessed on 11 June, 2020. 
of international society, states participate in international relations based on the idea of sovereign equality. As a result, the attribute of sovereignty encapsulates the state's superiority in carrying out the governors' will (Bartelson 2006). This is not to say that governments can abuse their power. Under international law, states have duties and responsibilities that limit the possibility of power abuse (Ginsburg 2020). Because human rights are the cornerstone of domestic law, all states, particularly authoritarian states, violate human rights implying that state sovereignty and human rights are inherently at odds. In light of that states continue to ratify treaties because international human rights treaties provide legitimacy prompting the degree to which states are socialized in international society affecting their decisions to ratify, even if at the cost of some sovereign independence (Wotipka and Tsutsui's 2008: 724-726).

An analogous perspective on sovereignty that has spawned so much complication is that sovereignty has undergone emendation and no longer entails absolute authority. As the international system has deemed necessary, the modern concept of sovereignty is relative and susceptible to restrictions (Delbruck 1982). The UN Charter does recognize the sovereign equality of member states. Hitherto in chapter $V I I$ it is also mentioned that the organization can interfere in sovereign states' policies if it is threatening international peace and security ${ }^{3}$. This paradoxical relationship of state sovereignty is not only limited to the legal and moral concept, but also extends further between state sovereignty and humanitarian intervention. Consequently, the difficulty the international community has had in reconciling forms of humanitarian intervention, including the Responsibility to Protect doctrine (2005), with practices of state sovereignty became apparent after Western intervention in Libya (2011) and subsequent vetoes by Russia and China humanitarian intervention in Syria (Donnelly 2003).

In China, the concept of sovereignty is the vital shield that is used under the semblance of counter-terrorism to buttress its activities in re-education camps in Xinjiang ${ }^{4}$. This is conceivable because the international counter-terrorism law provides a vague definition of terrorism which stands in infringement of the guidelines prepared by the UN Counter-Terrorism Implementation Task Forces. States,

3 UN Charter Ch VII provides a foundation within which the Security Council may take enforcement actions to uphold international peace and security by ending conflict applying measures not involving military force, or the use of military force to reinstate international peace and security (UNSC). We discussed that states should not hide human rights abuse or conduct human rights violations under the semblance of state sovereignty, available online at $<$ https://www.un.org/en/about-us/un-charter/ full-text>, accessed on 2 June 2020.

4 "China Focus: Xinjiang Determined in Counter-terrorism, Deradicalization, Maintaining Development," Xinhua Net, December 10, 2019, available online at $<$ http://www.xinhuanet.com/ english/2019-12/10/c_138618363.htm>, accessed on 5 June 2020.

5 The UN's global counter-terrorism strategy professes the inseparable connections between common human rights and security placing rule of law at the centre of all endeavours. The article emphasizes that despite forming a convention against international terrorism it has been hindered because of a lack of common consensus. The intensity of terrorism is not equivalent for all the states, in some states the severity could be less and while in some the new kind of political polarization could be highly intense leading to terrorist activities, available online at $<$ https://www.un.org/counterterrorism/unglobal-counter-terrorism-strategy>, accessed on 2 June 2020. 
mostly authoritarian states within the international human rights circle have kept the debate between universalism and relativism alive and controversial, rendering them unreconcilable. Their pushing of cultural relativism refuting human rights law exemplifies universal ideals and rights is (mis)use of relativism vis-à-vis human rights remarking that the ethical systems develop in the context of local cultures and universal application of it should not be assumed (Good 2010). Fernando R. Teson's evaluated elaborately different facets of cultural relativism, i.e. strong and weak, concluding that cultural relativism is not the right approach to address human rights concerns (Teson 1985). In contemporary context the international human rights law may be imperfect, but it symbolizes the inspired response for the international community. And, insistent on adopting the entirety of relativist argument dismisses the prospects of objectivity a blockade to observe beyond one's own culture bound reality (Kanarek 2013).

Ironically, to marginalize the universality of universal human rights norms, cultural relativist endorses that there exist no universal laws, norms, or principles but actively promote being tolerant towards different cultures underpinning tolerance as a de facto truth. Although recognizing the universal character of human rights in the 1993 international Vienna Declaration and Programme of Action ${ }^{6}$, the states support the cultural relativist argument because of the political benefits it provides to powerful elites. Nevertheless, misuse of it could result in individuals and minority groups being unprotected from the government (Zechenter 1997). Theoretical arguments by Jack Donnelly on relative universality approach that human rights are (relatively) universal as a concept whereas for particular rights relativity is not impregnable but anticipated (Donnelly 2007). Authoritarian or non-Western regimes have utilized this stance to promote relativism, as well as its idea of sovereignty and non-interference principle (Carrai 2019). However, this is where the inconsistency lies. Such states claim cultural uniqueness that differs from Western constructs but adheres to Western state sovereignty principles. Universal human rights are understandably justified because they give protection from all structures and institutions, including modern states and churches. Because of the potential for misbehaviour based on relativist reasoning, such as states citing human rights violations as an excuse to settle internal unrest or human rights violations in the name of economic development, universalism has the upper hand as a guardian over cultural relativism (Osinbajo 2004).

6 The Vienna Declaration of 1993, comprising of 171 delegations from UN member states crafted a document calling for a more meticulous understanding of human rights and stipulated ways to protect them. However, consistence challenge from states such as China, Colombia, Cuba, Iran, Iraq and others on the universality of human rights emphasize human rights as a western construct which we have attempted to discuss in the article by linking it to the mis(uses) of it. United Nations Human Rights Office of the High commissioner, available online at <https:/www.ohchr.org/en/aboutus/ pages/viennawc.aspx>, accessed on 2 June 2020. 


\section{China's notion of human rights: analysis of China's double-standard diplomacy}

China's rhetoric on universality has been characterized by ambiguity. Theoretically, China has emphasized Confucianism arguing that there was no need for the individual guarantee of protection from the state (Kent 1994). Strands of Confucianism paved the path for China's human rights debate. Chinese theorists Luo Mingda and $\mathrm{He}$ Hangzhou disclosed that China emphasized general (公) characteristics of rights while downplaying individual (私) features of rights. In other words, the whole notion of Chinese human rights discourse rests on the rights to subsistence (生存) and development (Angle 2002). This account brings into consideration a human right with Chinese characteristics (中國特色人權) and China's human rights diplomacy (Nathan 1994). China's interpretation of human rights contradicts the universality principle. It claims that human rights in their current form are inherently 'Western' (Fukuyama 1989). Therefore, China is attempting to set the precedent that human rights are the antithesis to development, and it is essential to prioritize economic rights over civil and political rights.

China was debating human rights in the 1970s-80s. However, the 1989 Tiananmen Square incident demonstrated to the West that there was no hope for China imitating the West, and the former was exposed to worldwide criticism for human rights breaches. Young men returned to the streets with posters advocating for human rights and political and economic reforms, but the international community intervened by putting pressure (Svensson 2002). The issue of integration was the major difference between the 1970s and 1990s. The latter year was the decade of pressure, so it responded to Western criticism and also used defensive human rights diplomacy to strengthen the bilateral relationship with several Western and neighbouring states to avoid isolation (Wan 2001). If not, China would have ignored Western criticism just as it did during the Cultural Revolution (Chen 2009: 400-405).

China's advancement in human rights diplomacy was noted by the world (as was the limited popular participation). On the one hand, China was a global participant, signing treaties and incorporating international laws into its foreign policy. On the other hand, it was struggling with socialization because of its refusal to ratify treaties such as the Rome Statute ${ }^{7}$, which established the International Criminal Court (ICC) and which calls into question sovereignty and territorial authority (Tao 2015: 1093-1096). China's normative human rights rhetoric included the publication of multiple White Papers (WP), which set the tone for human rights diplomacy. Deng Xiaoping was the driving force behind this shift in pragmatism, which aided China in systematically achieving its objectives. However, China's unmoved rigidity on the concept of sovereignty and non-interference (Wu 2010) is helping it to garner the backing of like-minded states. Therefore, we examine three hypotheses about the impact of China's double-standard diplomacy and build our case on the findings that

7 See, Rome Statue of the International Criminal Court, available online at $<$ https://legal.un.org/icc/ statute/99_corr/cstatute.htm>; and The International Criminal Court: A Commentary on the Rome Statute, Oxford Commentaries on International Law, 2016. 
China has mounted an unprecedented challenge to the international human rights regime's ability to avoid state accountability for human rights violations.

The first hypothesis examines the relationship between the WP, human rights centres, and Peace Keeping Operation (PKO) status and China's normative discourse on human rights, namely, whether China has been able to cultivate its normative space on human rights discourse. The second hypothesis examines China's sway over like-minded states and its ability to change the international human rights regime. The third hypothesis proposes that China just needs more time to either amend the existing treaties or adopt new resolutions that suit its purposes, allowing it to deflect criticism of human rights violations with the help of like-minded states.

Hypothesis 1: The more China focusses on WPs human rights research centres, counter-criticism and PKOs, the more the probability of fostering space for its normative discourse on human rights.

China's priority under Deng Xiaoping's leadership was global engagement and participation in an established normative discourse. China joined the Convention on Prevention and Punishment of the Crime of Genocide, Convention to the Status of Refugees, the International Convention on the Elimination of All Forms of Racial Discrimination, Convention on the Suppression and Punishment of the Crime of Apartheid, the Convention on the Elimination of All Forms of Discrimination against Women, the Convention against Torture and other Cruel Inhuman or Degrading Treatment or Punishment. China also signed both the ICCPR and the ICESCR, albeit only the latter was approved in 2001 (Potter 2007: 709-710).

Apart from adhering to agreements and issuing WPs, China's normative diplomacy also included the development of human rights research centres. Between 1991 and 2021, the State Council's Information Office released more than dozens of WPs honouring China's achievements in human rights, focusing on the right to subsistence and development rather than civil and political rights ${ }^{8}$. The 1990s WP focus was on economic progress and $1991 \mathrm{WP}$ was portrayed as a significant step in Chinese foreign policy (Kinzelbach 2016). However, the WP in the 2000s depicted improvements in China's human rights in all areas. Since 2014, there has been a pattern in the issuance of WPs. The CCP not only described its achievements in human rights in great detail but was also followed by a slew of official WPs produced in 2016, 2017, 2018, 2019, 2021.The most recent WPs - 'Moderate Prosperity in All Respects: Another Milestone Achieved in China's Human Rights' 2021', 'Human

8 China timely released White Papers on human rights to foster its space for human rights diplomacy. The first WP released in the 1990s introduces the efforts and achievements China has achieved, this was followed by emphasizing safeguarding citizens' legitimate civil and political rights in the 2000s. The focus of the WP shifted from the developments achieved to economic development being the top priority in China as stipulated by China's philosophy "China's White Paper on Human Rights China Human Rights. CN," China Society for Human Rights Studies, available online at $<$ http:// www.chinahumanrights.org $/ \mathrm{html} /$ special $/ 20180305 /$ ?pc hash $=U 1 \mathrm{a} 3 \mathrm{a} 0>$, accessed on 4 November 2020.

9 "China Issues White Paper on Human Rights Progress Through Moderate Prosperity Attainment," Xinhua Net, 12 August 2021, available online at <http://www.xinhuanet.com/english/202108/12/c_1310122626.htm>, accessed on 15 August 2021. 
Rights in Xinjiang-Development and Progress' $2017^{10}$ and 'China's Policies and Practices on Protecting Religious Belief' $2018^{11}$ revealed China's vigilant posture and human rights efforts. Thus, the WPs had done its functionality, it acted as a catalyst in fostering a normative discourse space, intended to shape the international human rights regime. In order to expand its normative space China's coordinated action plan was designed to respond to allegations raised against it as well as raise the degree of activism. In 1996, China issued its first response to a Human Rights Watch (HRW) study alleging inexplicable deaths of children in Chinese orphanages. In response, the CCP published an article in the People's Daily criticizing the situation of children in the US (Wan 2001). In 1998, China commemorated a symposium to celebrate the 50th anniversary of the Universal Declaration of Human Rights (Huang 2012: 16). China created the bimonthly newspaper 'Human Rights' in 2002, sending a message to the world that it welcomes debate and collaboration on human rights issues ${ }^{12}$. The attitude adopted was to expose the West's hypocrisy. When domestic atrocities occur, the West exploits human rights as a cynical tool to prevent China (and other states) from developing ${ }^{13}$.

China under Xi Jinping's leadership has maintained its counter-criticism strategy. At the 31 st Convention of the UNHRC 12 Western states led by the US claimed human rights violation in China were not taken lightly. China issued a statement reminding the US that, while it deems itself a human rights advocate, it has major human rights issues ${ }^{14}$. As part of the 'whataboutery' series, one of the human rights research centres, China Society for Human Rights Studies (CSHRS), recently produced a report on 'US-style human rights' ${ }^{15}$, as well as the US Rights Record released by the State Council Information Office in $2017^{16}$. The purpose was to win the trust of like-minded states by utilizing the rhetoric politically criticizing the US which has committed human rights violations. Simultaneously, the indulgence of

10 "Human Rights in Xinjiang Development and Progress," The State Council People's Republic of China, 1 June 2017, available online at <http://english.www.gov.cn/archive/white_paper/2017/06/01/ content 281475673512156.htm>, accessed on 5 November 2020.

11 "China Policies and Practices on Freedom of Religious Belief," The State Council People's Republic of China, 3 April 2018, available online at <http://www.china.org.cn/government/whitepaper/ node 8004087.htm>, accessed on 5 November, 2020.

12 "Chinese Minister Zhao Qizheng Views Country's Human Rights Progress," Permanent Mission of the People's Republic of China to the United Nations, 2002, available online at $<\mathrm{http}$ ://www.chinaun.ch/eng/rqrd/jzzdh/t85140.htm>, accessed on 10 November 2020.

13 "Human Rights Used by West Countries as Tool of Political Manipulation: Chinese Ambassador to UN," Global Times, 25 February 2021, available online at <https://www.globaltimes.cn/ page/202102/1216523.shtml>, accessed on 10 March 2021.

14 "West Not the Guardian of Human Rights," China Daily, 15 March, 2016, available online at <https:// www.chinadaily.com.cn/opinion/2016-03/15/content_23866802.htm>, accessed on 25 November 2020.

15 "China Releases Article Exposing US-Style Human Rights Hypocrisy," CGTN, 9 July , 2020, available online at <https://news.cgtn.com/news/2020-07-09/China-releases-article-exposing-U-Sstyle-human-rights-hypocrisy-RYKQ7GZY52/index.html>, accessed on 28 November 2020.

16 "Human Rights Record of the United States in 2016," The State Council of the People's Republic of China, 9 March, 2017, available online at <http://english.www.gov.cn/archive/ publications/2017/03/09/content_281475589785800.htm>, accesses on 25 November 2020. 
Chinese scholarly work created a cushion effect with descriptions of human rights, WP, and concepts for meeting international human rights standards and protecting human rights, popularizing China's human rights model (Sun 2014). On a worldwide scale, activity to promote China's human rights model persisted intensely. In a sideline meeting organized by China's Permanent Mission to the United Nations in New York on October 25, 2019, Zhang Jun reminded the world that rights to subsistence and development were the most important human rights priorities, given the global development imbalance ${ }^{17}$. These techniques are based on China's high regard for public diplomacy, which Hu Jintao described as "a key approach for the dissemination of Chinese culture" while Xi Jinping has made public diplomacy a priority ${ }^{18}$. In 2012, the party report of the CCP's 18th National Congress called for "excellent efforts to develop public diplomacy," which became the core concept of "telling a good tale of China” (講好中國故事) ${ }^{19}$. Thus, telling a good story = propaganda.

Three significant human rights research centres of China include CSHRS, founded in 1993, which is the largest national non-governmental organization (NGO) and has consultative status with the UN Economic and Social Council (ECOSOC). The CASS, which was established in 1977, is directly under the State Council's supervision, whereas the Beijing Children's Legal Aid and Research Center (BCLARC) was established in 1993.The goal of these institutions is to help China's human rights diplomacy develop a normative framework. For instance, during Beijing's second periodic assessment of the UN Human Rights Council (HRC) in October 2013 and March 2014, CSHRS conducted briefings for other human rights $\mathrm{NGOs}^{20}$. It also functioned as a network and facilitator in 2019, when a group travelled to Germany and Ireland for a seven-day tour and met with ambassadors, parliamentarians, and higher education experts ${ }^{21}$. The CASS's principal mission is to carry out CCP's research projects and organize academic contacts with other states supported by the Ministry of Foreign Affairs (MOFA) ${ }^{22}$. And BCLARC and Beijing Zhicheng

17 "China's human rights development path, achievements applauded at UN side event," Xinhua Net, 27 October 2019, available online at $<\mathrm{http}: / / w w w . x i n h u a n e t . c o m /$ english/2019-10/27/c_138507784. $\mathrm{htm}>$, accessed on 12 November 2020.

${ }^{18} \mathrm{Hu}$ Jintao was the first to mention public diplomacy as a means of improving China's relationship with other states while boosting soft power and national interests. Xi Jinping has pushed it forward because he recognizes the importance of opinion in international relations and in creating influence; as a result, 'telling a good narrative' has become a key guide in public diplomacy to promote Chinese viewpoints.

19 "Shibada baogao quanwen" (Full Text of the Party Report of the 18th National Congress), Xinhua Net, 19 November 2012, available online at $<$ http://www.xj.xinhuanet.com/2012-11/19/c_113722546_11. $\mathrm{htm}>$, accessed on 11 October 2020.

20 "On the Public Diplomacy of China in the Human Rights Fields," China Human Rights.CN, 12 April 2016, available online at <http://www.chinahumanrights.org/html/2016/MAGAZINES_0412/4752. html >, accessed on 12 September 2020.

21 "Delegation of China Society for Human Rights Studies Visits Germany, Ireland," Xinhua Net, 19June2019, availableonline at<http://www.xinhuanet.com/english/2019-06/19/c_138155431.htm>, accessed on 16 September 2020.

${ }^{22}$ See, Chinese Academy of Social Sciences, Chinese Government's Official Web Portal, available online at $<$ http://casseng.cssn.cn/ $>$. 
Legal Aid and Research Centre for Migrant Workers in 2011 the ECOSOC on legal aid services for migrant workers ${ }^{23}$. Later that year they were granted consultative status. China has realized the importance and benefits of GONGOS, or civil society organizations, in raising the international profile of such institutions and bolstering its diplomatic space (Hsu 2016). Although in comparison to other international NGOs, China's NGO existence is incapacitated but still has an upper hand because it utilizes its privilege of permanent member status at the UN Security Council to deny/ block the membership of non-P5 states' NGOs (Zhang 2017).

PKO is the most recent addition to expand China's consultation space and reach international institutions in order to further its human rights diplomacy. Throughout the 1980s, China abstained from voting on UN peacekeeping resolutions. The first cadre of peacekeeping personnel from China was sent to Cambodia in $1992^{24}$, simultaneously it continued to abstain on non-consensual peacekeeping resolutions such as ethnic cleansing in Yugoslavia and the Rwandan genocide ${ }^{25}$. China began attempts to improve its PKO status in the 2000s (Figure 1), a trend that has continued since Xi Jinping assumed power in 2013. The year 2015 was notable for China since

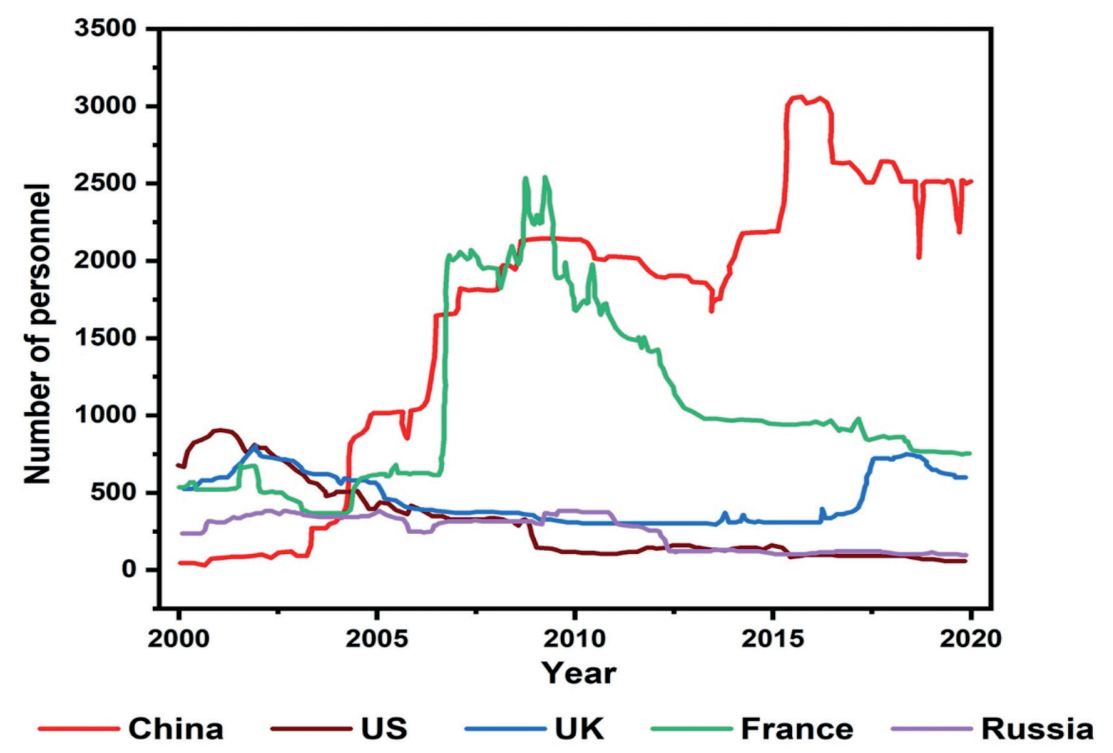

Figure 1. Exemplifies China's PKO status from 2000-2020. Source: UN PKO Contributions Note: The data include total contributions in the number of troops, police officers and election observation contributed by P5 states.

23 "Beijing Zhicheng Migrant Workers Legal Aid and Research Center, Organization" in Special Consultative Status with the Economic and Social Council," 2011, available online at $<$ https:// zgnmg.org/>, accessed on 10 September 2020.

${ }^{24}$ See, United Nations Security Council, Resolution 745 (1992), S/Res/745, 28 February 1992.

${ }^{25}$ United Nations Security Council, Resolution 794 (1992), S/Res/794, 3 December 1992. 
the number of peacekeeping personnel deployed by it increased to 3,048, and it has remained at over 2,500, the highest number of any P5 member ${ }^{26}$. China was the second-largest contributor to UN peacekeeping operations, making the climate ideal for the expansion of China's international influence (Nichols 2019).

\subsection{Reshaping of the international UN norms}

Liberal democratic norms and rules underpin the existing international order and human rights framework. However, under Xi Jinping's leadership, China called for global governance reform in 2018, posing an unprecedented challenge to the liberal rules-based system from an authoritarian state ${ }^{27}$. The $\mathrm{UN}$ is the alleged prime target because it is the apex institution and China also released a WP on foreign policy in 2019 underscoring the $\mathrm{UN}$ as the crux of global governance backs the statement ${ }^{28}$. However, it cannot be denied that traces of China's activism on reforming global governance was antecedent. It took an active role in presenting arguments on R2P, an example of the contestation to the concept of human rights, at the UN and developed a dialogical relationship that was only possible because of the rekindling of the diverse debate on human rights (Zhang and Buzan 2019: 17).

Hypothesis 2: The more support China secures from third world countries to its human rights model the greater the likelihood of China being able to reshape the established international human rights norms.

$\mathrm{Xi}$ Jinping's goal is to make China's model of national development the new global governance and human rights standard. Events such as the Beijing Forum on Human Rights (2008-2015), and South-South Human Rights Forum (December 2017) are integral to China's international normative campaign on human rights (Chen and Hsu 2020). The waning of the US influence from the international institutions complements China's endeavour to target multilateral institutions in the weakening of the liberal hegemonic order. The US withdrawal from the HRC (Foulkes 2018), cutting off its contribution to the UN's budget, China gaining the UN's influential seat, contributed in enhancing its influence (Gramer 2018). China's acting deputy Permanent Representative to the UN mission, Yao Shaojun, provided a lauded justification for China's consistent payments to the UN budget and peacekeeping missions (Lederer 2020).

China has come so ahead with its activeness related to relativism. It was the first time in the 1990s that China officially demonstrated its commitment to relativity. The case was about Convention Against Torture (CAT) and China submitted its relativist

${ }^{26}$ Personnel data is based on "Troop and police contributors," United Nations Peacekeeping, available online at $<$ https://peacekeeping.un.org/en/troop-and-police-contributors $>$, accessed on 10 December 2020.

27 "Xi Calls for Reforms on Global Governance," CGTN, 28 June 2018, available online at $<$ https:// news.cgtn.com/news/3d59544f354d7a6333566d54/index.html>, accessed on 12 October 2020.

28 "China and the World in the New Era," The State Council Information White Paper, Xinhua Net, 27 September, 2019, available online at <http://www.xinhuanet.com/english/201909/27/c_138427541.htm>, accessed on 15 October 2020. 
arguments suggesting reviewing the definition of torture as stated in its domestic law. It requested to encompass the definition of torture as stated in domestic law. Receiving a remark from a member of the State Session Committee that China had no specific definition of torture incorporated into its legislation, it reverted to a relativist justification that the definition of torture varies, and that something liberal for China may be unsuitable for the rest of the world (WU 2020). With time China's utterances at the United Nations represent became a threat to the normative discourse of the international human rights regime (Krebs and Jackson 2007). An expert Federica D'Alessandra, co-chair of the International Bar Association (IBA) Human Rights Law Committee, has expressed concerns that China's growing power could limit the UN's ability to address human rights crimes (Mulrenan 2019).

The world watched China and its like-minded governments' alliance during the 41st session of the UN Human Rights Council on July 8, 2019. The Western states signed a letter condemning China's mass incarceration of the Uyghurs and other Turkic minorities in Xinjiang ${ }^{29}$ four days later like-minded states issued a letter backing its counter-terrorism efforts ${ }^{30}$. In connection to that is the threat that if China is successful in altering the human rights norms, then state-initiated genocide, pogroms, repression of minorities will become a common phenomenon immune from the critique on the grounds of state sovereignty over domestic affairs. China's approach does not endorse liberal values, its participation at international institutions and wielding influence among third-world states must serve as a wake-up call for transatlantic states. Table 1 not only shows that China has worked for decades to build a group of like-minded states but also voting patterns in the United Nations against imposing sanctions on authoritarian regimes.

\subsection{China's effectiveness in passing the resolutions at the UN}

As an expanding power Xi Jinping's signature vision of 'building a community of shared future for mankind' (建構人類命運共同體) was proposed for the first time in 2014 to address global challenges. The Chinese diplomats have promoted this in conjunction with the UN's Sustainable Development Goals (SDG) ${ }^{31}$. China's activism, regardless of whether or not it succeeds in passing a resolution, continues its activism, in an effort to progressively win the race. As a result, it would be interesting to decipher if China, as a major player, has the power to change the international human rights framework or is reliant on the $\mathrm{P} 2$ nexus and the participation of likeminded states.

29 "41st Session of the Human Rights Council," United Nations Human Rights Council, 24June-12 July 2019, available online at $<$ https://www.ohchr.org/EN/HRBodies/HRC/RegularSessions/Session41/ Pages/41RegularSession.aspx>, accessed on 12 October 2020.

30 "Ambassadors from 37 Countries issue Joint Letter to Support China on its Human Rights Achievements," Xinhua Net, 12 July, 2019, available online at $<$ http://www.xinhuanet.com/ english/2019-07/13/c 138222183.htm>, accessed on 10 August 2020.

${ }^{31}$ Commentary: Why President Xi Strongly Advocates Building Community with Shared Future" Xinhua Net, 22 September 2020, available online at <http://www.xinhuanet.com/english/202009/22/c_139388123.htm>, accessed on 10 October 2020. 
Table 1. China's negative votes on sanctions (2000-2019)

\begin{tabular}{|c|c|c|c|c|}
\hline Country & Date & Issue & $\begin{array}{l}\text { Resolution } \\
\text { NO. }\end{array}$ & $\begin{array}{c}\text { Vote } \\
\text { (Yes, No, Abstain) }\end{array}$ \\
\hline Afghanistan & $\begin{array}{l}19 \text { December } \\
2000\end{array}$ & $\begin{array}{c}\text { Impose arms embargo on } \\
\text { Taliban }\end{array}$ & 1333 & $13,0,2$ \\
\hline \multirow[t]{4}{*}{ Sudan } & $\begin{array}{l}30 \text { July } \\
2004\end{array}$ & $\begin{array}{c}\text { Impose arms embargo on } \\
\text { Darfur }\end{array}$ & $1556 \dagger$ & $13,0,2$ \\
\hline & $\begin{array}{l}29 \text { March } \\
2005\end{array}$ & $\begin{array}{c}\text { Sanctions to be extended } \\
\text { on Darfur }\end{array}$ & $1591 \dagger \dagger$ & $12,0,3$ \\
\hline & 25 April 2006 & Impose Sanctions & $1672 \dagger \dagger$ & $12,0,3$ \\
\hline & $\begin{array}{l}14 \text { October } \\
2010\end{array}$ & Impose arms embargo & $1945 \dagger$ & $14,0,1$ \\
\hline Zimbabwe & $\begin{array}{l}11 \text { July } \\
2008\end{array}$ & $\begin{array}{l}\text { Impose Eco. Sanctions } \\
\text { and arms embargo }\end{array}$ & NA* & $\begin{array}{l}\text { Vetoed by China } \\
\text { and Russia: } 9,5,1\end{array}$ \\
\hline Somalia & $\begin{array}{l}13 \text { October } \\
2009\end{array}$ & $\begin{array}{c}\text { Impose sanctions on } \\
\text { Eretria }\end{array}$ & $1907 \dagger$ & $13,1,1$ \\
\hline Eritrea & $\begin{array}{l}5 \text { October } \\
2011\end{array}$ & $\begin{array}{l}\text { Impose arms embargo } \\
\text { against Eritrea }\end{array}$ & $2023+\dagger$ & $13,0,2$ \\
\hline Libya & $\begin{array}{l}17 \text { March } \\
2011\end{array}$ & $\begin{array}{l}\text { Ban on Libyan Arab } \\
\text { Jamahiriya airspace }\end{array}$ & $1973 \dagger \dagger$ & $10,0,5$ \\
\hline \multirow[t]{2}{*}{ Syria } & $\begin{array}{l}4 \text { October } \\
2011\end{array}$ & Impose arms embargo & NA* & $\begin{array}{c}\text { Vetoed by China } \\
\text { and Russia: } 9,2,4\end{array}$ \\
\hline & $\begin{array}{l}19 \text { July } \\
2012\end{array}$ & Impose sanctions on Syria & NA* & $\begin{array}{l}\text { Vetoed by China } \\
\text { and Russia: } 11,2,2\end{array}$ \\
\hline Venezuela & $\begin{array}{l}28 \text { February } \\
2019\end{array}$ & Holding new elections & & $\begin{array}{l}\text { Vetoed by Russia } \\
\text { and China: } 9,3,3\end{array}$ \\
\hline
\end{tabular}

Sources : UN Official Document System, UN Bibliographic Information System, UNSC.The table describes the sanctions, some also include omnibus issues, for example, peacekeeping. Resolutions with $*$ describe instances when China and Russia vetoed the resolution, $\dagger$ describe China abstain the resolution and $\dagger \dagger$ describe China and Russia abstain the resolution.

Note: China protected regimes with which it has good bilateral relations (including economic and military relations). 
Hypothesis 3: Irrespective of Russia's support China will be increasingly effective in passing the resolutions at the $\mathrm{UN}$.

China's partnership with like-minded states and its P2 nexus is robust. When the resolution on civil society space involvement with international and regional organizations was debated in 2018, China and Russia, as well as Pakistan and Cuba, voted against it, arguing that civil society should not interfere with member nations' sovereignty and territorial integrity ${ }^{32}$. For the Syrian conflict, China cast 11 vetoes and Russia eight, which demonstrate the P2 nexus camaraderie (Nichols 2019). In 2018 the $\mathrm{P} 2$ nexus was effective in blocking the high commissioner for human rights from speaking at the UN security council regarding human rights abuses in Syria (Lynch 2018). And in 2019 they opposed a draft resolution calling for a ceasefire in Syria's Idlib region later offered their own draft resolution allowing only Russia to continue military operations in Syria (Hernandez 2019) undermining the P3 influence.

Independently China is also stronger. Under Xi Jinping's leadership China has maintained economic relations with states against which the UN has mandated sanctions. A \$248 million loan agreement was signed in 2018 with South Sudan ${ }^{33}$ and China also abstained from the extended sanctions against it ${ }^{34}$. Similarly, when the United States drafted a resolution in 2019 asking for open and free elections and addressing the humanitarian catastrophe in Venezuela, China vetoed the resolution because of its economic interests and power politics (Grady 2019). Between the period 2014-2020 China frequently allied with like-minded states, although the latter faced criticism of their human rights record. The resolution drafted in 2019 to scrutinize the US, the P2 nexus, and like-minded states such as Iran, Venezuela joined in questioning the proceedings (Keaten 2020). Relatedly, a resolution against North Korea was opposed by China, Cuba and Venezuela (Renouard 2020) whereas in the case of Belarus, China raised the debate of state sovereignty and supported Belarus's opposition to a draft resolution on human rights sponsored by Bulgaria on behalf of the European Union (EU) ${ }^{35}$.

Congruently, China prepared to wield power in international institutions. It successfully ran twice for the HRC seat and was elected as a member for the 2021-

${ }^{32}$ See, A/HRC/38/L.17/Rev.1 Vote Item:3 - 38th Meeting, 38th Regular Session Human Rights Council, July 6 2018, available online at $<$ http://webtv.un.org/watch/ahrc381.17rev.1-vote-item338th-meeting-38th-regular-session-human-rights-council-/5806089049001>, accessed on 11 October 2020.

33 "South Sudan, China Ink \$248m Pact on Airspace Project," The State Council, The People's Republic of China, 26 January 2018, available online at $<$ http://english.www.gov.cn/news/international exchanges/2018/01/26/content_281476026093050.htm>, accessed on 11 September 2020.

34 "Security Council Renews Mandate of Expert Panel Overseeing South Sudan Arms Embargo by 12 Votes in Favour, None Against, 3 Abstentions, available online at $<$ https:/www.un.org/press/ en/2020/sc14199.doc.htm>, accessed on 11 January 2020.

${ }^{35}$ A/HRC/38/L.17/Rev.1 Vote Item:3 - 38th Meeting, 38th Regular Session Human Rights Council, July 06, 2018, available online at <http://webtv.un.org/watch/ahrc381.17rev.1-vote-item3-38thmeeting-38th-regular-session-human-rights-council-/5806089049001>, accessed on 11 October 2020. 
Table 2. Major Human Rights Council votes (2016-2018)

\begin{tabular}{|c|c|c|c|c|c|c|}
\hline \multirow{2}{*}{ Resolution Name } & \multirow{2}{*}{ Date } & \multicolumn{3}{|c|}{ Votes Count } & \multirow{2}{*}{ Result } & \multirow{2}{*}{$\begin{array}{l}\text { Russia/Like- } \\
\text { minded states } \\
\text { support }\end{array}$} \\
\hline & & Yes & Abstained & No & & \\
\hline $\begin{array}{l}\text { 1. Delegitimizing } \\
\text { human rights } \\
\text { defenders }\end{array}$ & $\begin{array}{c}22 \\
\text { March } \\
2016\end{array}$ & 15 & 10 & 21 & Failed & $\begin{array}{l}\text { Russia supported } \\
\text { the amendment }\end{array}$ \\
\hline $\begin{array}{l}* 2 \text {. Promoting } \\
\text { development over } \\
\text { human rights }\end{array}$ & $\begin{array}{l}22 \text { June } \\
2017\end{array}$ & 30 & 3 & 13 & Passed & $\begin{array}{c}\text { Like-minded } \\
\text { states supported }\end{array}$ \\
\hline $\begin{array}{l}\text { 3. Weakening } \\
\text { state obligations } \\
\text { to cooperate } \\
\text { with UNHRC } \\
\text { mechanisms }\end{array}$ & $\begin{array}{c}26 \\
\text { September } \\
2017\end{array}$ & 19 & 7 & 21 & Failed & $\begin{array}{l}\text { China co- } \\
\text { sponsored the } \\
\text { amendment with } \\
\text { Russia, Venezuela } \\
\text { and India }\end{array}$ \\
\hline $\begin{array}{l}* 4 \text {. Promoting } \\
\text { mutually beneficial } \\
\text { cooperation in the } \\
\text { field of human } \\
\text { rights }\end{array}$ & $\begin{array}{l}15 \\
\text { March } \\
2018\end{array}$ & 28 & 17 & 1 & Passed & $\begin{array}{l}\text { Like-minded } \\
\text { states supported } \\
\text { with EU bloc, } \\
\text { Japan and South } \\
\text { Korea abstaining }\end{array}$ \\
\hline $\begin{array}{l}\text { 5. Overseeing } \\
\text { Civil Society }\end{array}$ & $\begin{array}{l}\text { June } \\
2018\end{array}$ & 14 & 10 & 22 & Failed & $\begin{array}{c}\text { Like-minded } \\
\text { states supported }\end{array}$ \\
\hline $\begin{array}{l}\text { 6. Emphasizing } \\
\text { territorial } \\
\text { sovereignty }\end{array}$ & $\begin{array}{l}\text { June } \\
2018\end{array}$ & 15 & 10 & 21 & Failed & $\begin{array}{c}\text { Like-minded } \\
\text { states supported }\end{array}$ \\
\hline $\begin{array}{l}\text { 7. Decreasing state } \\
\text { cooperation with } \\
\text { civil society }\end{array}$ & $\begin{array}{l}\text { June } \\
2018\end{array}$ & 12 & 10 & 24 & Failed & $\begin{array}{c}\text { Like-minded } \\
\text { states supported }\end{array}$ \\
\hline
\end{tabular}

Sources: U.N. General Assembly, Amendment 31/L.47; U.N. Human Rights Council, Resolution HRC/35/L.33/ Rev.1; U.N. General Assembly, Amendment 36/L.51; U.N. Human Rights Council, Resolution HRC/37/L.36; Promoting mutually beneficial cooperation in the field of human rights, HRC/37/L.36; U.N. General Assembly, Amendment 31/L.47; U.N. General Assembly, Amendment 38/L.48; U.N. General Assembly, Amendment 38/L.39. Note: 1 - China's resolution targeting human rights defenders were supported by Russia, like-minded states and a few democracies which sought to weaken human rights defenders' protection; *2 - solo resolution by China got passed, transatlantic states voted no, human rights supporting middle powers abstained; 3 - the resolution was supported by P2 nexus, like-minded states and India including swing states, narrowly failed, leaving the high probability that it will be passed in coming years; * 4 - solo resolution presented by China was passed swiftly with only the US voting no and the EU bloc abstained; 5 - supported only by like-minded states critical of the existence of NGOs; 6 - China wanted to reduce the status/right of civil society to challenge state sovereignty (related to China's territorial issues over Xinjiang, Tibet, Taiwan), like-minded states voted yes; 7 - China had objection to the recommendation given by high commissioner for human rights that state and civil society should have robust engagement with each other. 
2023 term in an election held at the $75^{\text {th }}$ UN General Assembly ${ }^{36}$. Relating to human rights breaches in Belarus, Syria, and Eritrea for the 2015 Human Rights Council session China made 35 official interventions (Wintour 2018). Post 2015, China's activism evolved from Deng Xiaoping's famed 'hiding and biding time' to becoming more active and influential in international affairs. At the Human Rights Council, the P2 nexus and like-minded states partnership were active in drafting and introducing amendments to resolutions. From 2016 to 2018, a total of seven proposals were submitted, all of which were aimed at revising or changing UN resolutions. China has sponsored two resolutions using Chinese terminology on human rights and backed five amendments to resolutions submitted by allies which enhanced the principle of non-interference and by inference weakened civil society. Table 2 shows that China has the independent influence to get resolutions passed, it also indicates that China has a close partnership with Russia and like-minded states. Russia does not support China openly, but nor does it challenge it.

The finding from the analysis is that China just needs time. China-sponsored resolutions may pass in the future thanks to the support of like-minded and swing states and without needing Russia's support. However, it would be interesting to observe what happens if Russia challenges China, would that be a stumbling block or not?

\section{Human rights abuse in Xinjiang: a different chronicle}

The primacy of state sovereignty in China legitimizes a state's ability to coerce its own citizens in the name of sovereignty. Ethnic minorities in Xinjiang i.e., the Uyghurs, are oppressed under the guise of state sovereignty to safeguard China against terrorism. China's excessive repression of detaining over one million of the Uyghurs exhibits zero tolerance towards them (Zenz 2019). Because of the Chinese system's opaqueness, NGOs such as Amnesty International (AI), which reported on incommunicado detention of Uyghurs in detention centres ${ }^{37}$, and HRW which reported on Xinjiang becoming an Orwellian high-tech surveillance system have taken on the difficult task of naming and shaming ${ }^{38}$.

The international human rights regime is expressing concerns for the human rights abuse seeking to send a team to investigate the situation in Xinjiang, but China has given the matter the lens of sovereignty and non-interference ${ }^{39}$. Fifty UN special procedures, special rapporteurs, working groups, and other human rights experts

36 "China elected to Human Rights Council for 2021-2023," Xinhua Net, 14 October 2020, available online at <http://www.xinhuanet.com/english/2020-10/14/c_139438081.htm>, accessed on 20 October 2020.

${ }^{37}$ China 2019, Amnesty International, available online at $<$ https://www.amnesty.org/en/countries/asiaand-the-pacific/china/report-china/>, accessed on 10 January 2020.

38 "How Mass Surveillance Works in Xinjiang," Human Rights Watch, 2 May, 2019, available online at $<$ https://www.hrw.org/video-photos/interactive/2019/05/02/china-how-mass-surveillance-worksxinjiang $>$, accessed on 5 June 2020.

39 "China tells U.N. rights chief to respect its sovereignty after Xinjiang comments," Reuters, 11 September, 2018, available online at <https://www.reuters.com/article/us-un-rights-chinaidUSKCN1LR0L0>, accessed on 5 June 2020. 
published an in-depth assessment on China's human rights record in June 2020, highlighting the Chinese government's 'collective repression' of religious and ethnic minorities in Xinjiang and Tibet ${ }^{40}$. In October 2020, a cross-regional coalition of 39 states issued a searing public condemnation of China's human rights transgressions in Xinjiang, Hong Kong, and Tibet ${ }^{41}$. Recently on 14 September 2021 the High Commission for UN Michelle Bachelet told the UNHRC, "I regret that I am not able to report progress on efforts to seek meaningful access to the XUAR" (Xinjiang Uyghur Autonomous Region) suggests there has been a slow progress in calling China out ${ }^{42}$.

Xinjiang is a different chronicle because China under the shield of the internal matter is refuting the Uyghur community's basic human and cultural rights. The international community is currently divided into two camps, with more than 70 states, including Muslim states, backing and Western states striving to hold China accountable ${ }^{43}$. Certainly not in many cases, but China's ability to avoid international condemnation in the case of Xinjiang demonstrates the success of China's doublestandard diplomacy. China has competently created a normative space, but its actions are in discrepancy because in the case of Uyghurs it is overriding social and cultural rights despite ratifying ICESCR. As a result, China is establishing a significant trend of normalization for like-minded states to deploy coercive capability and condemn international human rights legislation intervention in domestic affairs. Therefore, China's human rights model $=$ development + prosperity is achieved at the expense of human rights abuse (Chung 2018).

The US, EU, UK and Canada, on 22 March 2021, collectively calling human rights abuses in Xinjiang a genocide issued coordinated sanctions on Chinese officials and entities to mount pressure ${ }^{44}$. Xi Jinping's strike hard policy since 2014 is systematically targeting the Uyghur identity through its assertive assimilation policy who are subjected to arbitrary incarceration, torture, sexual misconduct, including rapes, forced sterilization to eradicate their existence ${ }^{45}$. Extensive surveillance using

40 "UN experts call for decisive measures to protect fundamental freedoms in China," UN Human Rights Office of the High Commissioner, 26 June 2020, available online at $<$ https://www.ohchr.org/ EN/NewsEvents/Pages/DisplayNews.aspx?NewsID=26006>, accessed on July 12020.

41 "Statement by Ambassador Christoph Heusgen on behalf of 39 Countries in the Third Committee General Debate ," Permanent Mission of the Federal Republic of Germany to the United Nations, 6 October, 2020, available online at <https://new-york-un.diplo.de/un-en/news-corner/201006heusgen-china/2402648>, accessed on 1 November 2020.

42 "U.N. rights chief regrets lack of access to Xinjiang", Reuters, September 13, 2021, available online at $<$ https:/www.reuters.com/world/china/un-rights-chief-regrets-lack-access-xinjiang-2021-09-13/>, accessed on 16 September 2021.

43 "Nearly 70 countries voice support for China on human rights issues," CGTN, 8 October 2020, available online at $<\mathrm{https}$ //news.cgtn.com/news/2020-10-07/Nearly-70-countries-voice-supportfor-China-on-human-rights-issues-UnXxxhhFLi/index.html>, accessed on 20 November 2020.

${ }^{44}$ Uyghurs: MPs State Genocide is Taking place in China," BBC, 23 April 2021, https://www.bbc.com/ news/uk-politics-56843368>, accessed on 25 April 2021.

45 "Break Their Lineage, Break Their Roots - China's Crimes against Humanity Targeting Uyghurs and Other Turkic Muslims", Human Rights Watch, 19 April 2021, available online at <https://www. hrw.org/report/2021/04/19/break-their-lineage-break-their-roots/chinas-crimes-against-humanitytargeting\#_ftn11>, accessed on 25 April 2021. 
Integrated Joint Operation Platform ${ }^{46}$ has been set as a normalized trend by China to invade the Uyghurs' personal daily religious cultural practices characterizing that as fighting against counter-terrorism has been bought by like-minded states as it goes with the trend of states dealing with global Islamic terrorism (Greitens et al. 2020). This demonstrates China's capability in developing its normative space as a major actor in multilateral organizations with the power to amend, veto, and set an authoritative trend for the international human rights regime.

\section{Conclusion}

International human rights principles were created to apply equally to all states, but historical processes and uneven arguments about cultural relativism obstruct effective human rights protection and development. Investigating China's doublestandard diplomacy with theoretical conceptualization has revealed how, using a mix of relativism and activism, it has devised a strategy to demonize the status and terminology of universal human rights values. The article's empirical study both through data and text analysis underscores that China has a negative view towards the Western premise and that its human rights protect CCP's sovereignty. Through activism China has gained ground in bifurcating the international institutions into two camps. Xinjiang case aptly demonstrates that under the pretence of sovereignty principle a state can take liberty to conduct the worst of crimes against humanity. The Uyghurs' pursuit of basic cultural rights, such as freedom of expression, has been met with increased counter-terrorism measures, such as the establishment of detention facilities to indoctrinate the Uyghurs' minds and turn them into loyal citizens (if not to China) to the CCP. China's active human rights diplomacy and positive worldwide image of human rights progress do not encourage human rights protection, and Xinjiang is one example of human rights abuse in China, but it is far from the only one.

China's cultural relativist approach as an independent variable has an immense influence on like-minded states. It has a major explaining power in the elucidation of the factual assessment China enjoys as a persuasive player. On a wider scale the double-standard human rights diplomacy undertaken by states or the failure of the international community to even discuss human rights violations raises doubts about the notion of a globally recognized human rights regime. China being an influential power its emphasis on relativism has polarized the international human rights institutions, and how to work through this international human rights regime crisis and the human rights abuse in Xinjiang is a challenge for the Western states. Maybe reworking on conceptualization against relativism could be the beginning to take up this grander task.

46 "Interview: China's Big Brother App: Unprecedented View into Mass Surveillance of Xinjiang's Muslims," Human Rights Watch, 2019, available online at $<$ https://www.hrw.org/news/2019/05/01/ interview-chinas-big-brother-app>, accessed on 10 June 2020. 


\section{Acknowledgements}

Special thanks to Malcolm McKinnon, Adjunct Associate Professor, School of History, Philosophy, Political Science, and IR, Victoria University of Wellington, New Zealand and Mumin Chen, Professor, Graduate Institute of International Politics, National Chung Hsing University. The authors also benefitted from the critical discussion at the Taiwan Political Science Association (December 2020).

Addresses:

Sadia Rahman (corresponding author)

Graduate Institute of International Politics

9F Social Sciences and Management Building

National Chung Hsing University

145, Xingda Road

Taichung city 402

Taiwan (R.O.C)

E-mail: rahmansadia366@gmail.com

Wei-En Tan

National Chung Hsing University

4F-5 No 226, Yen-Ping S. Road

Taipei city 10065

Taiwan (R.O.C)

E-mail: jakobs@dragon.nchu.edu.tw

\section{References}

Angle, C. Stephen (2002) "Engagement despite distinctiveness". In Human rights and Chinese thought: a cross-cultural inquiry, 214-250. New York: Cambridge University Press.

Bartelson, Jens (2006) "The concept of sovereignty revisited". The European Journal of International Law 17, 2, 463-474. DOI: https://doi.org/10.1093/eji1/chl006

Burke, Ronald (2013) Decolonization and the evolution of international human rights. Pennsylvania: University of Pennsylvania Press.

Burnay, Matthieu (2020) "China's 'discourse power' and the rule of law at the national and international levels". In David Ismangil, Karen van der Schaaf, and Stijn Deklerck, eds. Shifting power and human rights diplomacy: China, 21-29. (Strategic Studies.) Amnesty International Netherlands.

Burton, Hafner, Emilie (2013) Making human rights a reality. New Jersey: Princeton University Press.

Carrai, Maria Adele (2019) Sovereignty in China: a genealogy of a concept since 1840. Cambridge: Cambridge University Press.

Chen, C. Chen and Chiahao Hsu (2020) "China's human rights foreign policy in the Xi Jinping era: normative revisionism shrouded in discursive moderation". The British Journal of Politics and International Relations 23, 2, 1-26. DOI: https://doi.org/10.1177/1369148120957611 
Chen, Dingding (2009) "China's participation in the international human rights regime: a state identity perspective". The Chinese Journal of International Politics 2, 3, 399-405. DOI: https://doi. org/10.1093/cjip/pop002

Chung, Peng. Chien (2018) "China's Uyghur problem after the 2009 Urumqi riot: repression, recompense, readiness, resistance". Journal of Policing, Intelligence, and Counter-Terrorism 13, 2, 186-210. DOI: https://doi.org/10.1080/18335330.2018.1475746.

Delbruck, Jost (1982) "International protection of human rights and state sovereignty," Indiana Law Journal 57, 4, 567-578.

Donnelly, Jack and Daniel J. Whelan (2020) “Theories of human rights”. International Human Rights, New York: Routledge.

Donnelly, Jack (2003) "Genocide and Humanitarian Intervention". Universal human rights in theory and practice, 242-258. London: Cornell University Press.

Donnelly, Jack (2007) “The relative universality of human rights". Human Rights Quarterly 29, 2, 281-306.

Forsythe, P. David (2000) Human rights in international relations. Cambridge: Cambridge University Press.

Foulkes, Imogen (2018) "Why did the US leave the UN Human Rights Council". BBC, 20 June. Available online at $<$ https://www.bbc.com/news/world-us-canada-44552304>. Accessed on 25 October 2021.

Fraser, Julie (2020) "Human rights and their cultural connection". In Social institutions and international human rights law implementation: every organ of society, 21-61. Cambridge: Cambridge University Press.

Fukuyama, Francis (1989) “The End of History?" The National Interest, 16, 3-18.

Fung, J. Courtney (2019) China and Intervention at the UN Security Council: Reconciling Status, (Oxford University Press)

Ginsburg, Tom (2020) "The machinery of international law and democratic backsliding: the problem of term limits". Law and Ethics of Human Rights 14, 1, 1-18. DOI: https://doi.org/10.1515/ lehr-2020-2012

Good, Colleen (2010) "Human rights and relativism". Macalester Journal of Philosophy 19, 4, 27-50.

Gotz, Elias and Camille Renaud Merien (2018) "Russia and the question of world order". European Politics and Society 20, 2. DOI: https://doi.org/10.1080/23745118.2018.1545181

Grady, O Mary (2019) "China vetoes Venezuelan freedom". The Wall Street Journal, 18 March. Available online at <https:/www.wsj.com/articles/china-vetoes-venezuelan-freedom$11552848410>$. Accessed on 25 October, 2021.

Gramer, Robbie and Colum Lynch (2018) “Trump stealthily seeks to choke off funding to U.N. programs”. Foreign Policy, 2 October. Available online at $<$ https://foreignpolicy.com/2018/10/02/trumpstealthily-seeks-to-choke-off-funding-to-un-programs/>. Accessed on 25 October, 2021.

Greitens, C. Sheena, Myunghee Lee, and Emir Yacizi (2020) "Counter-terrorism and preventive repression”. International Security 44, 3, 9-47. DOI: https://doi.org/10.1162/isec_a_00368

Hernandez, Michael (2019) "Russia, China veto Idlib cease-fire UN resolution". AA, 9 September. Available online at $<$ https://www.aa.com.tr/en/middle-east/russia-china-veto-idlib-cease-fireun-resolution/1588766>. Accessed on 25 October, 2021.

Hsu, YJ. Jennifer (2016) "The internationalisation of Chinese NGO". The Asia Dialogue, 29 September. Available online at $<$ https://theasiadialogue.com/2016/09/29/gongos-vs-ngosthe-internationalisation-of-chinese-ngos/>. Accessed on 25 October, 2021. 
Huang, Chin-Hao (2012) “Principles and praxis of China's Peacekeeping”. In Marc Lanteigne and Miwa Hirono, eds. China's evolving approach to peacekeeping, 16-28. London: Routledge.

Kanarek, Jaret (2013) "Critiquing cultural relativism". The Intellectual Standard 2, 1, 2-14.

Keaten, Jamey (2020) "China, Iran, join queue to scrutinize US at UN rights body". Associated Press, 10 November. Available online at $<\mathrm{https}$ //apnews.com/article/iran-geneva-immigration-chinaunited-nations-0830ae206737ca8a3983347a40638585>. Accessed on 25 October, 2021.

Kent, Ann (1994) Between freedom and subsistence: China and human rights. Oxford: Oxford University Press.

Kinzelbach, Katrin (2016) “China's white paper on human rights". Global Public Policy Institute. Available online at $<$ https://www.gppi.net/2016/04/05/chinas-white-paper-on-human-rights $>$. Accessed on 25 October, 2021.

Kliman, M. Daniel (2012) “The West and global swing states". Italian Journal of International Affairs 47, 3. DOI: https://doi.org/10.1080/03932729.2012.700017

Krebs, R. Ronald and Patrick Thaddeus Jackson (2007) "Twisting Tongues and twisting arms: the power of political rhetoric". European Journal of International Affairs 13, 1, 56-58. DOI: https://doi.org/10.1177/1354066107074284

Lederer, M. Edith (2020) "China goes after US over more than $\$ 1$ billion owed to the UN". CTV News, 15 May. Available online at $<$ https://www.ctvnews.ca/world/china-goes-after-u-s-over-morethan-1-billion-owed-to-the-un-1.4942282?cache=kcfnyoei $>$. Accessed on 25 October, 2021.

Lynch, Colum (2018) "At the UN, China and Russia score win in war on human rights". Foreign Policy, 26 March. Available online at $<$ https://foreignpolicy.com/2018/03/26/at-the-u-n-chinaand-russia-score-win-in-war-on-human-rights/>. Accessed on 25 October, 2021.

Martina, Michael (2018) "China tells U.N. rights chief to respect its sovereignty after Xinjiang comments". Reuters, 10 September. Available online at $<$ https://www.reuters.com/article/usun-rights-china-idUSKCN1LR0L0>. Accessed on 25 October, 2021.

McQuigg, J. A. Ronagh (2011) International human rights law and domestic violence: the effectiveness of international human rights law. London: Routledge.

Mulrenan, Stephen (2019) “China's designs for Human Rights”. International Bar Association, 12 February. Available online at $<$ https://www.ibanet.org/Article/NewDetail. aspx?ArticleUid=e0fd1a4a-e3e7-4f80-aefb-31eb339bf045>. Accessed on 25 October, 2021.

Nathan, J. Andrew (1994) "Human rights in Chinese foreign policy". The China Quarterly 622-643.

Nichols, Michelle (2019) "Russia backed by China, casts 14th UN veto on Syria to block cross-border aid". Reuters, 21 December. Available online at $<$ https://www.reuters.com/article/us-syriasecurity-un/russia-backed-by-china-casts-14th-u-n-veto-on-syria-to-block-cross-border-aididUSKBN1YO23V>. Accessed on 25 October, 2021.

Nichols, Michelle (2019) "U.N. Members owe \$2 billion in debt to peacekeeping, U.S. owes a third". Reuters, 18 January. Available online at $<$ https://www.reuters.com/article/us-un-peacekeepersusa-idUSKCN1PB2OD>. Accessed on 25 October, 2021.

Osinbajo, Yemi (2004) "Human rights, economic development and the corruption factor". In Paul Tiyambe Zeleza and Philip J. McConnaughay, eds. Human rights, the rule of law and development in Africa, 120-129. Philadelphia: University of Pennsylvania Press.

Piccone, Ted (2018) "China's long game on human rights at the United Nations," Brookings. Available online at <https://www.brookings.edu/wp-content/uploads/2018/09/FP_20181009_china_ human_rights.pdf $>$. Accessed on 25 October, 2021. 
Potter, B. Pitman (2007) "China and the international legal system: challenges of participation". The China Quarterly 191, 699-710.

Renouard, Joe (2020) "Sino-Western Relations, political values, and the Human Rights Council". Journal of Transatlantic Studies 18, 90-94. DOI: https://doi.org/10.1057/s42738-019-000359>. Accessed on 25 October, 2021.

Shambaugh, David (2020) "China's long march to global power". China and the world, 1-25. Oxford: Oxford University Press.

Sun, Pinghua (2014) Human rights protection system in China. Cham: Springer.

Svensson, Marina (2002) "The Domestic challenge over human rights: the democracy wall activists and the official reaction". In Debating human rights in China: a conceptual and political history, 233-260. Lanham, MD: Rowman and Littlefield.

Tao, Jing (2015) "China's socialization in the international human rights regime: why did China reject the rome statute of the international criminal court?". Journal of Contemporary China 24, 96, 1092-1096. DOI: https://doi.org/10.1080/10670564.2015.1030959.

Teson, R. Fernando (1985) "International human rights and cultural relativism". Virginia Journal of International Law 25, 869-898.

Wan, Ming (2001) Human rights and Chinese foreign relations: defining and defending national interests. Pennsylvania: University of Pennsylvania Press.

Wintour, Patrick (2018) "China starts to assert its world view at UN as influence grows". The Guardian, 24 September. Available online at $<$ https://www.theguardian.com/world/2018/sep/24/chinastarts-to-assert-its-world-view-at-un-as-influence-grows > . Accessed on 25 October, 2021.

Wotipka, M. Christine and Kiyoteru Tsutsui (2008) "Global human rights and state sovereignty: state ratification of international human rights treaties, 1965-2000”. Sociological Forum 23, 4, 724 754.

Wu, Chengqiu (2010) "Sovereignty, human rights, and responsibility: changes in China's response to international humanitarian crises". Journal of Chinese Political Science 15, 71-97. DOI: https://doi.org/10.1007/s11366-009-9083-5.

$\mathrm{Wu}$, Jingjing (2020) "A perspective of objectivity in international human rights treaties". International Journal for the Semiotics of Law 18-20. DOI: https://doi.org/10.1007/s11196-020-.

Xin, Liu (2020) "China elected Human Rights Council member, as Western attacks end in vain". Global Times, 13. October. Available online at $<$ https://www.globaltimes.cn/content/1203362. shtml\#: :text=China\%20on\%20Tuesday\%20was\%20elected,75th\%20United $\% 20$ Nations $\% 20$ General\%20Assembly.\&text=Five $\% 20$ member $\% 20$ states $\% 20 \% 2 \mathrm{D} \% 20 \mathrm{China} \% 2 \mathrm{C} \% 20 \mathrm{~N}-$ epal,to\%20the\%20Xinhua\%20News\%20Agency>. Accessed on 25 October, 2021.

Zechenter, M. Elizabeth (1997) "In the name of culture: cultural relativism and the abuse of the individual". Journal of Anthropological Research 53, 3, 324-341.

Zenz, Adrian (2019) "You can't force people to assimilate: so why is China at it again?". The New York Times, 16 July. Available online at <https://www.nytimes.com/2019/07/16/opinion/chinaxinjiang-repression-uighurs-minorities-backfire.html >. Accessed on 25 October, 2021.

Zhang, Wenjuan (2017) “The internationalization of Chinese NGOs and their engagement with the United Nations”. China Report 53, 3, 323-324. DOI: https://doi.org/10.1177/0009445517711507

Zhang, Yongjin and Barry Buzan (2019) "China and the global reach of human rights". The China Quarterly 241, 17. DOI: https://doi.org/10.1017/S0305741019000833 